Article

\title{
Enantio-selective preparation of ( $S$ )-1-phenylethanol by a novel marine GDSL lipase MT6 with reverse stereo-selectivity
}

\author{
Dun Deng a,b,c, Yun Zhang a,b, Aijun Sun a,b, Yunfeng Hu a,b,d,* \\ a Key Laboratory of Tropical Marine Bio-resources and Ecology, South China Sea Institute of Oceanology, Chinese Academy of Sciences, Guangzhou \\ 510301, Guangdong, China \\ ${ }^{\mathrm{b}}$ Guangdong Key Laboratory of Marine Materia Medica, South China Sea Institute of Oceanology, Chinese Academy of Sciences, Guangzhou, Guangzhou \\ 510301, Guangdong, China \\ c Institute of Animal Science, Guangdong Academy of Agricultural Science, Guangzhou 510640, Guangdong, China \\ d South China Sea Bio-Resource Exploitation and Utilization Collaborative Innovation Center, Guangzhou 510275, Guangdong, China
}

\section{A R T I C L E I N F O}

\section{Article history:}

Received 31 May 2016

Accepted 13 July 2016

Published 5 November 2016

\section{Keywords:}

GDSL lipase

Biocatalysis

Kinetic resolution

Direct hydrolysis

(S)-1-Phenylethanol

Reverse stereo-selectivity

\begin{abstract}
A B S T R A C T
We previously functionally characterized a novel marine microbial GDSL lipase MT6 and identified that the stereo-selectivity of MT6 was opposite to that of other common lipases in trans-esterification reactions. Herein, we have investigated the use of MT6 in stereo-selective biocatalysis through direct hydrolysis reactions. Notably, the stereo-selectivity of MT6 was also demonstrated to be opposite to that of other common lipases in hydrolysis reactions. Parameters, including temperature, organic co-solvents, $\mathrm{pH}$, ionic strength, catalyst loading, substrate concentration, and reaction time, affecting the enzymatic resolution of racemic 1-phenylethyl acetate were further investigated, with the e.e. of the final (S)-1-Phenylethanol product and the conversion being $97 \%$ and $28.5 \%$, respectively, after process optimization. The lengths of side chains of 1-phenylethyl esters greatly affected the stereo-selectivity and conversion during kinetic resolutions. MT6 is a novel marine microbial GDSL lipase exhibiting opposite stereo-selectivities than other common lipases in both trans-esterification reactions and hydrolysis reactions.
\end{abstract}

(C) 2016, Dalian Institute of Chemical Physics, Chinese Academy of Sciences. Published by Elsevier B.V. All rights reserved.

\section{Introduction}

The GDSL family enzymes are a new subclass of hydrolytic enzymes mostly identified in microorganisms [1-3] and plants [4-6]. GDSL enzymes contain distinct GDSL sequence motifs instead of the GxSxG sequence motifs in common lipases. The catalytic centers of GxSxG motifs in common lipases exist in the middle of the lipases, while the conserved GDSL sequence motifs exist at the N-terminus of GDSL enzymes [7,8]. Additional distinct features of GDSL enzymes are that GDSL enzymes do not contain the nucleophile elbow which generally exists in common lipases and that GDSL enzymes harbor flexible catalytic centers to coordinate different substrates. GDSL enzymes generally contain five sequence blocks (I-V) with four conserved catalytic residues (Ser, Gly, Asn, and His) in blocks I, II, III, and V, respectively. The four conserved residues play key roles in the catalytic activities of GDSL enzymes, so GDSL enzymes are also designated as a SGNH-hydrolase subfamily $[9,10]$.

To date, research regarding GDSL family enzymes mainly

\footnotetext{
* Corresponding author. Tel: +86-20-89024092; Fax: +86-20-84451672; E-mail: yunfeng.hu@scsio.ac.cn

This work was supported by the Strategic Priority Research Program of Chinese Academy of Sciences (XDA11030404), the National Natural Science Foundation of China (21302199), Guangzhou Science and Technology Plan Projects (201510010012), and the Key Project from Chinese Academy of Sciences (KGZD-EW-606).

DOI: 10.1016/S1872-2067(16)62505-6 | http://www.sciencedirect.com/science/journal/18722067 | Chin. J. Catal., Vol. 37, No. 11, November 2016
} 
focuses on studies related to the analysis of DNA sequences and protein sequences of GDSL enzymes [11]. Basic studies related to the biochemical properties of GDSL enzymes have also been reported [12,13]. Most characterized GDSL hydrolytic enzymes have exhibited hydrolysis activities of esterases, lipases, or proteases. Some research also focused on the catalytic mechanisms and crystal structures of GDSL hydrolytic enzymes [14].

However, using GDSL enzymes in industry has not been well reported, despite many esterases/lipases having been demonstrated capable of preparing valuable chiral chemicals through trans-esterification, direct hydrolysis, and esterification. Previously, we reported using MT6, a novel marine microbial GDSL lipase, in the preparation of chiral chemicals through trans-esterification reactions [15]. The enantio-selectivity and conversion of the kinetic resolution reactions catalyzed by GDSL esterase MT6 were quite satisfying after process optimization. More importantly, the enantio-selectivity of MT6 in the preparation of chiral chemicals through trans-esterification reactions was opposite to that of most common esterases and lipases (Scheme 1(a)).

Before our study, there was only one report, to the best of our knowledge, regarding the use of GDSL hydrolytic enzymes in the preparation of chiral chemicals through direct hydrolysis, and the enantiomeric excess (e.e.) of the final product was not very high (e.e. $=93 \%$ ) [16]. Herein, we investigated using marine microbial GDSL lipase MT6 in the preparation of a chiral secondary alcohol, (S)-1-phenylethanol, through direct enzymatic hydrolysis of an inexpensive racemic 1-phenylethyl acetate substrate. The enantiomeric excess and the conversion of the desired (S)-1-phenylethanol product were quite satisfying after process optimization. Interestingly and more importantly, during the process of kinetic resolution through direct hydrolysis, the enantio-selectivity of GDSL lipase MT6 was also opposite to that of common esterases and lipases (Scheme 1(b)).

\section{Experimental}

\subsection{Microorganisms and materials}

The strain Marinactinospora thermotolerans SCSIO 00652 was isolated from sediments collected from the northern South China Sea at a depth of 3865 m [17]. The host strains Escherichia coli $\mathrm{DH} 5 \alpha$ and $E$. coli BL21 (DE3) were obtained from Novagen (Novagen, USA). Vector pET-28a(+) for protein expression was also obtained from Novagen (Novagen, USA). $( \pm)$-1-Phenylethanol, (R)-1-phenylethanol, and (S)-1-phenylethanol were purchased from Aladdin Chemistry Corporation. Racemic 1-phenylethyl acetate, 1-phenylethyl propionate, and 1-phenylethyl butyrate were purchased from Adamas Reagent Co., Ltd. All other chemicals were commercially available and of pure analytic grade.

\subsection{Expression, purification, and lyophilization of GDSL lipase MT6}

Methods for constructing expression plasmid (pET28aMT6) and the heterologous expression of GDSL lipase MT6 are detailed elsewhere [15]. After induction at $25{ }^{\circ} \mathrm{C}$ for $16 \mathrm{~h}$, the cultured cells were harvested by centrifugation at $5000 \mathrm{r} / \mathrm{min}$ for $15 \mathrm{~min}$, washed twice with Tris-HCl buffer $(20 \mathrm{mmol} / \mathrm{L}, \mathrm{pH}$ $=8.0$ ), resuspended in the same buffer, and then disrupted by sonication on ice for $15 \mathrm{~min}$. The supernatants containing recombinant lipase MT6 were collected by centrifugation at $10000 \mathrm{r} / \mathrm{min}$ for $25 \mathrm{~min}$.

Lipase MT6 obtained from the supernatant of induced $E$. coli BL21(DE3)/pET28a-MT6 cells was lyophilized in a SCIENT$\mathrm{N} 10$ freeze dryer, and enzyme powders were stored at $-20{ }^{\circ} \mathrm{C}$ for the following biochemistry and resolution experiments.

\subsection{Enantio-selective hydrolysis of 1-phenylethyl acetate to (S)-phenylethanol}

\subsubsection{Effect of temperature}

The effect of temperature on the resolution of 1-phenylethyl acetate was studied using enzymatic reactions containing 50 $\mathrm{mg} / \mathrm{mL}$ lipase MT6 powder and $10 \mathrm{~mol} / \mathrm{L}$ racemic 1-phenylethyl acetate in $500 \mu \mathrm{L}$ buffer $(25 \mathrm{mmol} / \mathrm{L}, \mathrm{pH}=8.0)$. The hydrolysis reactions of 1-phenylethyl acetate by GDSL lipase MT6 were performed at various temperatures ranging from 20 to $60{ }^{\circ} \mathrm{C}$ at $200 \mathrm{r} / \mathrm{min}$ for $12 \mathrm{~h}$. Afterwards, $500 \mu \mathrm{L}$ of ethyl acetate was used to extract the residual 1-phenylethyl



Scheme 1. Enantio-selective preparation of $(R)$-1-phenylethanol and $(S)$-1-phenylethanol by marine microbial GDSL lipase MT6 through (a) trans-esterification reactions and (b) direct hydrolysis reactions, respectively. 
acetate and 1-phenylethanol from the enzymatic hydrolysis reactions and for further analysis using chiral GC.

\subsubsection{Screening of organic co-solvents}

To study the effect of organic co-solvents on the resolution of 1-phenylethyl acetate, $500 \mu \mathrm{L}$ of enzymatic reactions containing $50 \mathrm{mg} / \mathrm{mL}$ lipase MT6 powder, $10 \mathrm{mmol} / \mathrm{L}$ 1-phenylethyl acetate, and 10\% (V/V) of different organic co-solvents in Tris-HCl buffer $(25 \mathrm{mmol} / \mathrm{L}, \mathrm{pH}=8.0)$. The enzymatic hydrolysis reactions of racemic 1-phenylethyl acetate by GDSL lipase MT6 were performed at $40{ }^{\circ} \mathrm{C}$ and $200 \mathrm{r} / \mathrm{min}$ for $12 \mathrm{~h}$, and then the enzymatic reactions were extracted using $500 \mu \mathrm{L}$ of ethyl acetate three times and further analyzed by chiral GC.

\subsubsection{Effect of $\mathrm{CH}_{2} \mathrm{Cl}_{2}$ concentration}

The effect of concentration of $\mathrm{CH}_{2} \mathrm{Cl}_{2}$ on the resolution of 1-phenylethyl acetate was studied using enzymatic reactions containing $50 \mathrm{mg} / \mathrm{mL}$ lipase MT6 powder and $10 \mathrm{mmol} / \mathrm{L}$ 1-phenylethyl acetate in Tris-HCl buffer ( $25 \mathrm{mmol} / \mathrm{L}, \mathrm{pH}=8.0$ ). Various concentrations of $\mathrm{CH}_{2} \mathrm{Cl}_{2}$ ranging from $2.5 \%$ to $25 \%$ were added to the enzymatic hydrolysis reactions, and the hydrolysis reactions were performed at $40{ }^{\circ} \mathrm{C}$ and $200 \mathrm{r} / \mathrm{min}$ for $12 \mathrm{~h}$. Afterwards, the enzymatic reactions were extracted using $500 \mu \mathrm{L}$ of ethyl acetate three times and further analyzed by chiral GC.

\subsubsection{Effect of $p H$}

To study the effect of $\mathrm{pH}$ on the kinetic resolution of 1-phenylethyl acetate, the enzymatic hydrolysis reactions of racemic 1-phenylethyl acetate were performed by carrying out $500-\mu \mathrm{L}$ enzymatic reactions harboring $50 \mathrm{mg} / \mathrm{mL}$ lipase MT6 powder, $10 \mathrm{mmol} / \mathrm{L}$ racemic 1-phenylethyl acetate, and 5\% $(V / V)$ of $\mathrm{CH}_{2} \mathrm{Cl}_{2}$ in buffers with $\mathrm{pH}$ ranging from 5.0 to 10.0 : acetic acid/sodium acetate ( $\mathrm{pH}=5.0$ to 6.0 ), potassium phosphate ( $\mathrm{pH}=6.0$ to 6.5$)$, Tris- $\mathrm{HCl}$ ( $\mathrm{pH}=7.0$ to 8.5), and Glycine $/ \mathrm{NaOH}(\mathrm{pH}=9.0$ to 10.0$)$. The above enzymatic reactions were performed at $40{ }^{\circ} \mathrm{C}$ and $200 \mathrm{r} / \mathrm{min}$ for $12 \mathrm{~h}$, and then the reactions were extracted using $500-\mu \mathrm{L}$ of ethyl acetate three times and analyzed by chiral GC.

\subsubsection{Effect of ionic strength}

The effect of ionic strength (0-1 mol/L) on the kinetic resolution of racemic 1-phenylethyl acetate was tested using 500- $\mu \mathrm{L}$ enzymatic reactions harboring $50 \mathrm{mg} / \mathrm{mL}$ lipase MT6 powder, $10 \mathrm{mmol} / \mathrm{L}$ racemic 1-phenylethyl acetate, and 5\% $(\mathrm{V} / \mathrm{V})$ of $\mathrm{CH}_{2} \mathrm{Cl}_{2}$ in Tris-HCl buffer with $\mathrm{pH}$ 7.0. The above kinetic resolution of racemic 1-phenylethyl acetate by GDSL lipase MT6 was performed at $40{ }^{\circ} \mathrm{C}$ and $200 \mathrm{r} / \mathrm{min}$ for $12 \mathrm{~h}$. Afterwards, the enzymatic reactions were extracted using $500 \mu \mathrm{L}$ of ethyl acetate three times and further analyzed by chiral GC.

\subsubsection{Effect of catalyst loading}

To investigate the effect of catalyst loading on the resolution of 1-phenylethyl acetate, enzymatic kinetic resolution reactions containing $20 \mathrm{mg} / \mathrm{mL}$ to $200 \mathrm{mg} / \mathrm{mL}$ lipase MT6 powder, 10 $\mathrm{mmol} / \mathrm{L}$ racemic 1-phenylethyl acetate, and $5 \%(\mathrm{~V} / \mathrm{V})$ of $\mathrm{CH}_{2} \mathrm{Cl}_{2}$ in Tris-HCl buffer $(100 \mathrm{mmol} / \mathrm{L}, \mathrm{pH}=7.0)$. The kinetic resolu- tion reactions of racemic 1-phenylethyl acetate by MT6 were performed at $40{ }^{\circ} \mathrm{C}$ and $200 \mathrm{r} / \mathrm{min}$ for $12 \mathrm{~h}$, and then the enzymatic reactions were extracted using $500-\mu \mathrm{L}$ of ethyl acetate three times and analyzed by chiral GC.

\subsubsection{Effect of substrate concentration}

For the investigation of substrate concentration on the kinetic resolution of racemic 1-phenylethyl acetate, enzymatic reactions containing $150 \mathrm{mg} / \mathrm{mL}$ lipase MT6 powder, 5\% (V/V) of $\mathrm{CH}_{2} \mathrm{Cl}_{2}$, and racemic 1-phenylethyl acetate with concentrations ranging from $5 \mathrm{mmol} / \mathrm{L}$ to $20 \mathrm{mmol} / \mathrm{L}$ in Tris- $\mathrm{HCl}$ buffer (100 mmol/L, $\mathrm{pH}=7.0$ ) were conducted. The above enzymatic kinetic resolution reactions were performed at $40{ }^{\circ} \mathrm{C}$ and 200 $\mathrm{r} / \mathrm{min}$ for $12 \mathrm{~h}$. Afterwards, the enzymatic reactions were extracted using $500-\mu \mathrm{L}$ of ethyl acetate three times and further analyzed by chiral GC.

\subsubsection{Time course}

To study the resolution time course of racemic 1-phenylethyl acetate, $500-\mu \mathrm{L}$ enzymatic kinetic resolution reactions containing $150 \mathrm{mg} / \mathrm{mL}$ lipase MT6 powder, $15 \mathrm{mmol} / \mathrm{L}$ 1-phenylethyl acetate, and $5 \%(V / V)$ of $\mathrm{CH}_{2} \mathrm{Cl}_{2}$ in Tris- $\mathrm{HCl}$ buffer $(100 \mathrm{mmol} / \mathrm{L}, \mathrm{pH}=7.0)$ were conducted. The enzymatic reactions were shaken at $40{ }^{\circ} \mathrm{C}$ and $200 \mathrm{r} / \mathrm{min}$. The time course of the kinetic resolution reactions was monitored by extracting residual 1-phenylethanol and 1-phenylethyl acetate from enzymatic reactions using $500 \mu \mathrm{L}$ of ethyl acetate three times every $2.5 \mathrm{~h}$ and then further analyzed by chiral GC.

\subsubsection{Kinetic resolution of 1-phenylethyl esters of different chain lengths}

To investigate the effect of 1-phenylethyl esters of different chain lengths on the kinetic resolution, three 1-phenylethyl esters (1-phenylethyl acetate, 1-phenylethyl propionate, and 1-phenylethyl butyrate) were chosen for the enzymatic kinetic resolution reactions catalyzed by MT6. Standard 500- $\mu$ L enzymatic reactions contained $150 \mathrm{mg} / \mathrm{mL}$ lipase MT6 powder, 1-phenylethyl esters with concentrations ranging from 5 $\mathrm{mmol} / \mathrm{L}$ to $20 \mathrm{mmol} / \mathrm{L}$, and $5 \%(\mathrm{~V} / \mathrm{V})$ of $\mathrm{CH}_{2} \mathrm{Cl}_{2}$ in Tris- $\mathrm{HCl}$ buffer $(100 \mathrm{mmol} / \mathrm{L}, \mathrm{pH}=7.0)$. The above enzymatic reactions were performed at $40{ }^{\circ} \mathrm{C}$ and $200 \mathrm{r} / \mathrm{min}$ for $12 \mathrm{~h}$; then, the reaction system was extracted with $500-\mu \mathrm{L}$ of ethyl acetate three times and further analyzed by chiral GC.

\subsection{Analytical methods}

After the termination of the enzymatic reactions, the residual 1-phenylethanol and 1-phenylethyl acetate were extracted three times using $500 \mu \mathrm{L}$ of ethyl acetate and further analyzed by chiral GC. The enantiomeric excess (e.e.) of (S)-1-phenylethanol, conversion $(C)$ of 1-phenylethyl acetate, and enantiomeric ratio $(E)$ of enzymatic reactions were calculated using the equation of Chen et al. [18].

A gas chromatograph (FULI GC-9790 II) equipped with a 112-6632 CYCLOSIL-B chiral capillary column (30 m $\times 0.25$ $\mathrm{mm} \mathrm{ID,} 0.25 \mu \mathrm{m} \mathrm{df}$ ) was used to analyze the residual 1-phenylethanol and 1-phenylethyl acetate from the enzymatic 
reactions. The temperatures of the $\mathrm{H}_{2}$ flame ionization detector and injector were set at 250 and $280{ }^{\circ} \mathrm{C}$, respectively. Nitrogen served as the carrier gas at a split flow rate of $1.20 \mathrm{~mL} / \mathrm{min}$. The oven temperature was held at $100{ }^{\circ} \mathrm{C}$ for $1 \mathrm{~min}$, then increased at $10^{\circ} \mathrm{C} / \mathrm{min}$ to $220^{\circ} \mathrm{C}$ and held for $3 \mathrm{~min}$.

\section{Results and discussion}

\subsection{Phylogenetic analysis}

Based upon the analysis of protein sequences, GDSL esterases/lipases can generally be classified into five clades (I-V). GDSL lipases identified from the microorganisms generally belong to clade I or clade II [7]. A distance-based phylogenetic tree of GDSL lipase MT6 and other GDSL lipases was constructed and indicated that the GDSL lipase MT6 we studied belonged to clade I of GDSL hydrolases.

\subsection{Kinetic resolution of 1-phenylethyl acetate}

\subsubsection{Effect of temperature}

To investigate the effect of temperature on the kinetic resolution of racemic 1-phenylethyl acetate, standard enzymatic reactions were incubated at $20-60{ }^{\circ} \mathrm{C}$ (Fig. 1). The conversion of 1-phenylethyl acetate to $(S)$-1-phenylethanol increased from 20 to $40{ }^{\circ} \mathrm{C}$ and decreased from 40 to $60{ }^{\circ} \mathrm{C}$. The highest conversion was obtained at $40{ }^{\circ} \mathrm{C}$. The effect of temperature on the conversion was possibly due to the temperature increase from 20 to $40{ }^{\circ} \mathrm{C}$ stimulating the hydrolysis activity of MT6, and the temperature increase from 40 to $60{ }^{\circ} \mathrm{C}$ denaturing MT6. The enantio-selectivity of MT6 toward racemic 1-phenylethyl acetate basically remained unchanged at temperatures ranging from 20 to $40{ }^{\circ} \mathrm{C}$ and decreased when the temperature of the enzymatic reactions was increased from 40 to $60^{\circ} \mathrm{C}$. Thus, 40 ${ }^{\circ} \mathrm{C}$ was characterized as the optimum working temperature for the highest conversion and the highest enantio-selectivity during the enzymatic kinetic resolution of racemic 1-phenylethyl acetate catalyzed by GDSL lipase MT6.

\subsubsection{Effect of organic co-solvents}

To study the effect of organic co-solvents on the enzymatic kinetic resolution of racemic 1-phenylethyl acetate, nine organic solvents with $\log P$ ranging from -1.1 to 4.5 were added to standard enzymatic kinetic reactions at a concentration of $10 \%$ $(V / V)$. As shown in Table 1 , the addition of extra organic co-solvents could greatly affect both the enantio-selectivity and conversion of the kinetic resolution of racemic 1-phenylethyl acetate by GDSL lipase MT6. The highest e.e. for the (S)-1-phenylethanol product (89\%) and the highest conversion (24.6\%) were obtained when using dichloromethane as the organic co-solvent, compared with the e.e. of $43 \%$ and conversion of $23 \%$ in control reactions without the addition of organic co-solvents. We also observed that the addition of the other eight organic co-solvents could greatly decrease the conversion during kinetic resolution, possibly because the addition of those organic co-solvents greatly affected the hydrolysis activity by denaturation. The trend of the effect of organic



Fig. 1. Effect of temperature on the kinetic resolution of 1-phenylethyl acetate.

co-solvents on the kinetic resolution did not correlate with the $\log P$ values of the tested organic co-solvents. Therefore, dichloromethane was determined to be the optimum organic co-solvent in the kinetic resolution of racemic 1-phenylethyl acetate by GDSL lipase MT6.

\subsubsection{Effect of organic co-solvent concentration}

The concentration of organic co-solvents could affect both the enantio-selectivity and the conversion of kinetic resolution catalyzed by lipases and esterases. Subsequently, after dichloromethane was determined to be the optimal organic co-solvent for the kinetic resolution of racemic 1-phenylethyl acetate by GDSL lipase MT6, we also investigated the effect of concentration of dichloromethane $(2.5 \%-30 \%, V / V)$ on the kinetic resolution of 1-phenylethyl acetate by MT6. As shown in Fig. 2, the e.e. of the $(S)$-1-phenylethanol product $(90 \%)$ remained high and basically unchanged when dichloromethane was added to the enzymatic reactions at concentrations ranging from $5 \%$ to $25 \%$. However, the highest conversion of the kinetic reaction $(26 \%)$ was obtained when dichloromethane was added at a concentration of 5\%, and the conversion greatly decreased with increasing dichloromethane concentration. Consequently, $5 \%$ was determined to be the optimal concentration of the organic co-solvent dichloromethane during the kinetic resolution of racemic 1-phenylethyl acetate.

Table 1

Effect of organic co-solvents on the kinetic resolution of 1-phenylethyl acetate.

\begin{tabular}{lcccc}
\hline Co-solvent & $\log P$ & e.e. $(\%)$ & $C(\%)$ & $E$ \\
\hline CK & & 43 & 23 & 2.84 \\
1,4-dioxane & -1.1 & 36 & 20 & 2.32 \\
Isopropanol & 0.38 & 61 & 17 & 4.70 \\
tert-Butanol & 0.6 & 65 & 11.5 & 5.14 \\
Dichloromethane & 1.01 & 89 & 24.6 & 22.82 \\
Toluene & 2.5 & $<1$ & 8 & $<1$ \\
Cyclohexane & 3.2 & $<1$ & 6 & $<1$ \\
n-Hexane & 3.5 & 2 & 10 & $<1$ \\
$n$-Heptane & 4.0 & $<1$ & 8 & $<1$ \\
Isooctane & 4.5 & $<1$ & 9 & $<1$ \\
\hline
\end{tabular}




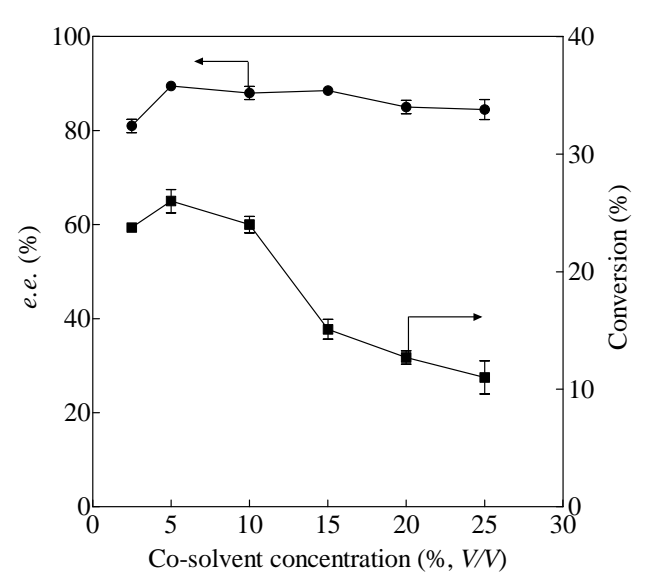

Fig. 2. Effect of dichloromethane concentration on the kinetic resolution of 1-phenylethyl acetate.

\subsubsection{Effect of $p H$}

$\mathrm{pH}$ could greatly affect both the enantio-selectivity and the conversion of hydrolases during the process of enzymatic kinetic resolution possibly by modifying the ionic states of both enzymes and substrates. To determine the optimal $\mathrm{pH}$ for the enzymatic kinetic resolution of racemic 1-phenylethyl acetate by MT6, standard enzymatic reactions were carried out at a pH ranging from 5.0 to 10.0 .

As shown in Fig. 3, the highest conversion for the kinetic resolution of racemic 1-phenylethyl acetate by MT6 (26\%) was obtained at $\mathrm{pH}=7.0$, and the conversions at other $\mathrm{pH}$ values were much lower. Meanwhile, the highest e.e. of the (S)-1-phenylethanol product (94\%) was also obtained at $\mathrm{pH}=$ 7.0, and the enantio-selectivity of MT6 greatly decreased when the $\mathrm{pH}$ was higher than 7.5. Thus, $\mathrm{pH}=7.0$ was determined to be the optimal $\mathrm{pH}$ for the enzymatic kinetic resolution of racemic 1-phenylethyl acetate by GDSL lipase MT6.

\subsubsection{Effect of ionic strength}

The buffer ionic strength is another important parameter that may affect the activity and enantio-selectivity of hydrolases during the process of enzymatic kinetic resolution. To investigate the effect of ionic strength on both the conversion and



Fig. 3. Effect of $\mathrm{pH}$ on the kinetic resolution of 1-phenylethyl acetate.

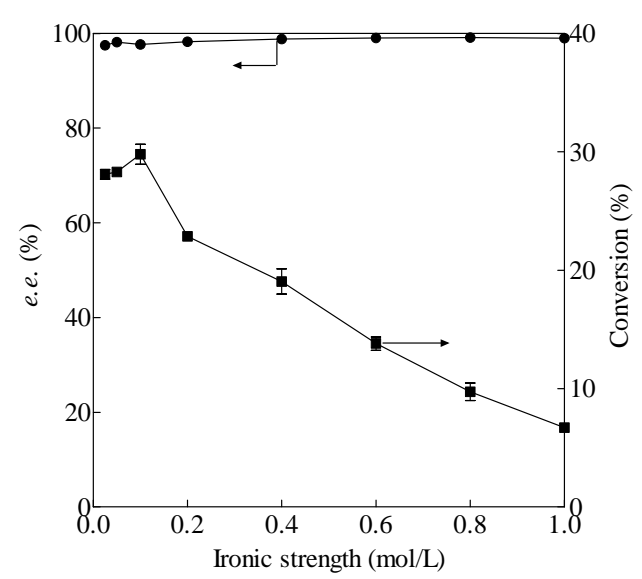

Fig. 4. Effect of ionic strength on the kinetic resolution of 1-phenylethyl acetate.

the enantio-selectivity in the kinetic resolution of racemic 1-phenylethyl acetate by GDSL lipase MT6, enzymatic reactions of different ionic strengths ranging from 0.025 to $1.0 \mathrm{~mol} / \mathrm{L}$ were performed. As shown in Fig. 4, the e.e. of (S)-1-phenylethanol product remained very high $(>97 \%)$ when the kinetic resolution reactions of racemic 1-phenylethyl acetate by MT6 were carried out in buffers with ionic strengths ranging from 0.1 to $1.0 \mathrm{~mol} / \mathrm{L}$. However, the conversions of the enzymatic reactions were observed to be strongly affected by the ionic concentrations of buffer. The highest conversion was obtained when the ionic strength was $0.1 \mathrm{~mol} / \mathrm{L}$, and the conversions quickly decreased when the ionic strength was greater than $0.1 \mathrm{~mol} / \mathrm{L}$. Thus, $0.1 \mathrm{~mol} / \mathrm{L}$ was determined to be the optimal ionic strength for the enzymatic kinetic resolution of racemic 1-phenylethyl acetate by GDSL lipase MT6.

\subsubsection{Effect of catalyst loading}

As enzymes are generally quite expensive, catalyst loading is an important economic parameter to consider during enzymatic synthesis. The key is to identify the optimal catalyst loading for the generation of products with the best quality. To investigate the optimal catalyst loading for the kinetic resolution of racemic 1-phenylethyl acetate by GDSL lipase MT6, MT6 of different concentrations ranging from 25 to $200 \mathrm{mg} / \mathrm{mL}$ was added to standard enzymatic reactions. As shown in Fig. 5, the kinetic resolution conversion of racemic 1-phenylethyl acetate by MT6 increased with increasing catalyst loading of MT6, and the conversion remained basically unchanged when the catalyst loading was greater than $150 \mathrm{mg} / \mathrm{mL}$. The e.e. of the (S)-1-phenylethanol product slightly decreased from $98 \%$ to $95.3 \%$ with the increase of catalyst loading from 25 to 200 $\mathrm{mg} / \mathrm{mL}$. Given the effect of catalyst loading on both the conversion and enantio-selectivity, $150 \mathrm{mg} / \mathrm{mL}$ was determined to be the optimal catalyst loading for the kinetic resolution of racemic 1-phenylethyl acetate by MT6.

\subsubsection{Effect of substrate concentration}

Substrate concentration can also greatly affect the kinetic resolution reactions catalyzed by hydrolases. To investigate the 




Fig. 5. Effect of catalyst loading on the kinetic resolution of 1-phenylethyl acetate.

effect of substrate concentration on the kinetic resolution of racemic 1-phenylethyl acetate by MT6, different substrate concentrations ranging from 2.5 to $20 \mathrm{mmol} / \mathrm{L}$ were added to the enzymatic kinetic resolution reactions. As shown in Fig. 6, after enzymatic reactions with different substrate concentrations for $25 \mathrm{~h}$, the conversion slightly decreased from $38.7 \%$ to $34.4 \%$ with the increase of substrate concentrations from 5 to $15 \mathrm{mmol} / \mathrm{L}$. When the substrate concentration was increased to $20 \mathrm{mmol} / \mathrm{L}$, the conversion was approximately $23 \%$ at $25 \mathrm{~h}$. Meanwhile, the e.e. of the (S)-1-phenylethanol product essentially remained unchanged. Considering the effect of substrate concentration on both conversion and enantio-selectivity, 15 $\mathrm{mmol} / \mathrm{L}$ was characterized as the optimal substrate concentration during the kinetic resolution of racemic 1-phenylethyl acetate by MT6.

\subsubsection{Reaction time course}

The effect of reaction time on the kinetic resolution of racemic 1-phenylethyl acetate by MT6 was also studied by analyzing residual substrates and products from standard enzymatic reactions at different time points. As shown in Fig. 7, the e.e. of

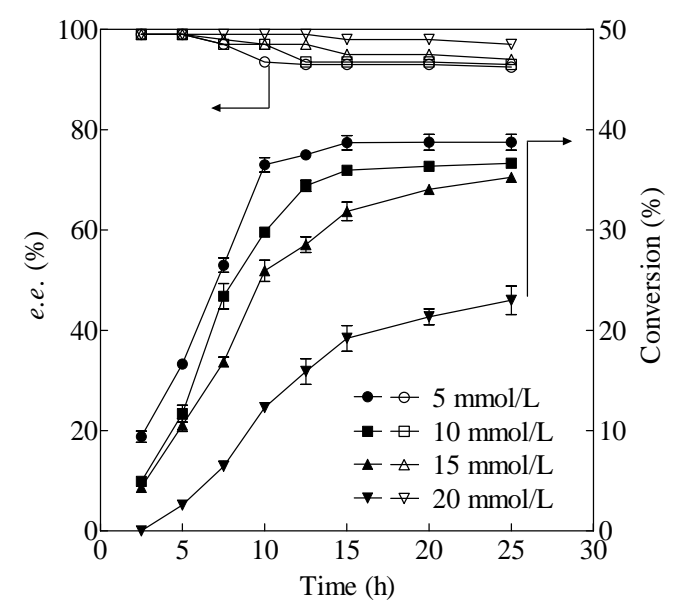

Fig. 6. Effect of substrate concentration on the kinetic resolution of 1-phenylethyl acetate.

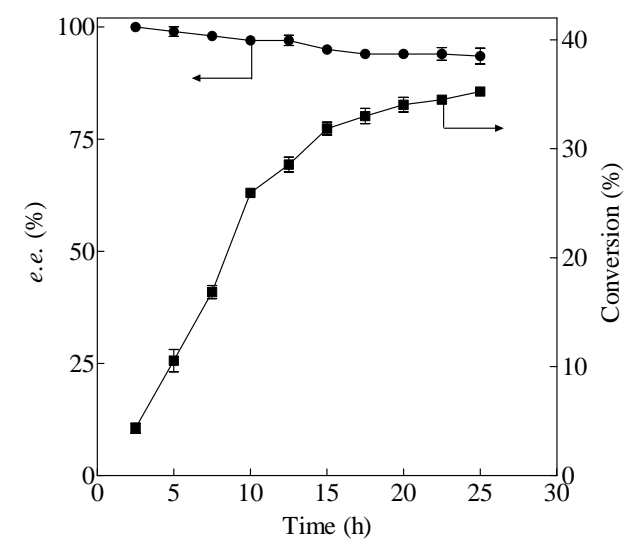

Fig. 7. Effect of reaction time on the kinetic resolution of $( \pm)$-1-phenylethanol acetate.

the $(S)$-1-phenylethanol product remained high (> 97\%) in the beginning $12 \mathrm{~h}$ and slightly decreased after $12 \mathrm{~h}$. The conversions of the enzymatic kinetic resolution reactions continued to increase with increasing time and essentially remained constant after $25 \mathrm{~h}$. Given the effect of reaction time on both the enantio-selectivity and conversion, $12 \mathrm{~h}$ was determined to be the optimal reaction time for the kinetic resolution of racemic 1-phenylethyl acetate by MT6, with the conversion greater than $28.5 \%$.

\subsubsection{Kinetic resolution of 1-phenylethyl esters of different chain lengths}

After optimizing the kinetic resolution of racemic 1-phenylethyl acetate by MT6, we also investigated the kinetic resolution of 1-phenylethyl esters with different chain lengths by MT6. Under optimal enzymatic working conditions, 1-phenylethyl esters of different chain lengths (1-phenylethyl acetate, 1-phenylethyl propionate, and 1-phenylethyl butyrate) were added to standard kinetic resolution reactions catalyzed by MT6. As shown in Table 2, with increasing side chain length, the e.e. of the (S)-1-phenylethanol product decreased, and the conversion increased. Therefore, the length of the side chain of 1-phenylethyl esters could greatly affect the enantio-selectivity of MT6, and short-chain 1-phenylethyl ester (1-phenylethyl acetate) was the substrate that generated the chiral product with the highest optical purity. The conversion increased with increasing side chain length possibly because the butyric acid side-product was a relatively weak acid and could not easily denature biocatalyst MT6.

The 3D structure of MT6 was modeled by Swiss-Mode Server [19]. MT6 shared $31.33 \%$ identity with an esterase (PDB

\section{Table 2}

Effect of different substrates on the kinetic resolution of 1-phenylethyl acetate.

\begin{tabular}{lccrc}
\hline Substrate & e.e. $(\%)$ & $C(\%)$ & \multicolumn{1}{c}{$E$} & Activity (U/mg) \\
\hline 1-Phenylethyl acetate & 97.0 & 28.5 & 95.9 & 5.93 \\
1-Phenylethyl propionate & 89.7 & 32.0 & 33.7 & 6.67 \\
1-Phenylethyl butyrate & 50.0 & 34.0 & 3.8 & 7.08 \\
\hline
\end{tabular}





Fig. 8. 1-Phenylethyl esters were docked with the 3D structure of MT6. (a) (R)-1-phenylethyl acetate; (b) $(R)$-1-phenylethyl butyrate.

code: 1esc) from Streptomyces scabies [20]. The activity site of MT6 consisted of Ser12, Glu54, Asp89, and His230 (Fig. 8). His230 in the active-site of GDSL lipase MT6 functions with both Ser12 and the enantio-preferred substrate through hydrogen bonds. However, the longer side chains of ester substrates can deter the ester bond from contacting the imidazole group of His230. Thus, the stereo-specificity of MT6 was lower during the hydrolysis of racemic 1-phenylethyl esters of longer side chains.

3.3. Comparison of the stereo-selectivity of MT6 with those of other common lipases/esterases in the resolution of 1-phenylethyl acetate

During the kinetic resolution of racemic esters, common lipases or esterases generally stereo-selectively catalyze the trans-esterification of the $R$ enantiomer of racemic alcohols and hydrolyze the $R$ enantiomer of racemic esters. Thus, the configuration of final products after enzymatic kinetic resolution catalyzed by common lipases or esterases could be deduced based upon this empirical rule.
GDSL lipases are a new class of hydrolases, the detailed functions of which have not been well characterized before. The exploration of GDSL lipases in stereo-selective biocatalysis is also quite rare. Previously, we identified and functionally characterized the function of this novel microbial GDSL lipase MT6 from the deep sea of the South China Sea. We also used GDSL lipase MT6 in enzymatic kinetic resolution through trans-esterification reactions. Interestingly, GDSL lipase MT6 could stereo-selectively esterify the $S$ enantiomer of racemic esters instead of the $R$ enantiomer, so the stereo-selectivity of GDSL lipase MT6 was opposite to that of other common lipases and esterases during enzymatic trans-esterification reactions [21-25]. For example, one lipase LC2-8 from Pseudomonas stutzeri could esterify the $R$ enantiomer of racemic 1-phenylethanol and generate $(S)$-1-phenylethanol with a yield of $47.6 \%$ and an e.e. $>99 \%$ [25].

In our work, we also investigated the stereo-selectivity of GDSL lipase MT6 in stereo-selective biocatalysis through direct hydrolysis. Notably, GDSL lipase MT6 could stereo-selectively hydrolyze the $S$ enantiomer of 1-phenylethyl acetate instead of the $R$ enantiomer. As shown in Table 3, before our study of MT6, there were reports about the stereo-selective kinetic resolution of 1-phenylethyl acetate, and all of the other lipases and esterases stereo-selectively hydrolyzed the $R$ enantiomer of 1-phenylethyl acetate [26-29]. Hence, the stereo-selectivity of GDSL lipase MT6 in enzymatic kinetic resolution through direct hydrolysis was also opposite to that of other common lipases and esterases and did not follow the empirical rule for lipases and esterases.

Although GDSL lipase MT6 could generate optical purity of $(R)$-1-phenylethanol with high enantiomeric excess (e.e. > 99\%) through trans-esterification reactions, the enantiomeric excess of $(S)$-1-phenylethanol prepared from the hydrolysis reactions catalyzed by MT6 was not as high as in trans-esterification reactions. This may be due to the different solubility of substrates in the aqueous and organic phases, or the configurations of amino acids in the active site were also affected by the reaction medium [30]. The native stereo-selectivity of MT6 could also affect the optical purity of the final chiral product. We may combine trans-esterification reactions with hydrolysis reactions to further improve the optical purity of (S)-1-phenylethanol generated from hydrolysis reactions.

\section{Conclusions}

We previously functionally characterized a novel microbial GDSL lipase MT6 and used it in stereo-selective kinetic resolu-

Table 3

Comparison of the stereo-selectivity of MT6 with that of other common lipases/esterases in the resolution of 15 mmol/L 1-phenylethyl acetate.

\begin{tabular}{lcccc}
\hline Enzyme & $\begin{array}{c}\text { Reaction time } \\
(\mathrm{h})\end{array}$ & $\begin{array}{c}\text { Conversion } \\
(\%)\end{array}$ & $\begin{array}{c}\text { e.e. } \\
(\%)\end{array}$ & Configuration \\
\hline MT6 & 12 & 28.5 & 97 & $S$ \\
Lipase from Porcine Pancreatic & - & 54 & 53 & This work \\
Candida rugosa lipase & 76 & 33 & 24 & $R$ \\
Carboxylesterase from Escherichia coli K-12 & - & 37.4 & 99 & $R$ \\
Esterase from Bacillus sp. SCSIO 15121 & 8 & 49 & 99 & $R$ \\
\hline
\end{tabular}


tion through trans-esterification reactions. The stereo-selectivity of MT6 was interestingly opposite to that of other common lipases/esterases and could stereo-selectively prepare optically pure $(R)$-1-phenylethanol instead of $(S)$-1-phenylethanol prepared by other common lipases/esterases through trans-esterification reactions. In this study, we also investigated the ability of GDSL lipase MT6 in stereo-selective biocatalysis through direct hydrolysis of racemic esters. We found that the stereo-selectivity of GDSL lipase MT6 was also opposite to that of other common lipases/esterases. GDSL lipase MT6 hydrolyzed racemic 1-phenylethyl acetate and generated $(S)$-1-phenylethanol instead of $(R)$-1-phenylethanol produced by other common lipases/esterases. The optical purity and conversion of the $(S)$-1-phenylethanol product were also quite satisfying after optimization of the process. Meanwhile, we also identified that the lengths of side chains in 1-phenylethyl esters could greatly affect the e.e. and conversion during enzymatic kinetic resolutions. In conclusion, we demonstrated that MT6 is a novel microbial GDSL lipase identified from the South China Sea that exhibited opposite stereo-selectivities to other common lipases/esterases in both trans-esterification reactions and direct hydrolysis reactions.

\section{Acknowledgments}

We would like to thank the constant help from Professor Jianhua Ju and Professor Changsheng Zhang.

\section{References}

[1] Z. X. Yang, Y. Zhang, T. T. Shen, Y. Xie, Y. M. Mao, C. N. Ji, J. Biosci. Bioeng., 2013, 115, 133-137.

[2] O. Alalouf, Y. Balazs, M. Volkinshtein, Y. Grimpel, G. Shoham, Y. Shoham, J. Biol. Chem., 2011, 286, 41993-42001.

[3] Y. Okamura, T. Kimura, H. Yokouchi, M. Meneses-Osorio, MKatoh, T. Matsunaga, H. Takeyama, Mar. Biotechnol., 2010, 12, 395-402.

[4] X. L. Tan, S. Z. Yan, R. K. Tan, Z. Y. Zhang, Z. Wang, J. Chen, Protein J.,
2014, 33, 18-23.

[5] K. J. Kim, J. H. Lim, J. K. Kim, T. Kim, H. M. Chung, K. H. Paek, Biochem. Biophys. Res. Commun., 2008, 374, 693-698.

[6] M. Muralidharan, K. Buss, K. E. Larrimore, N. A. Segerson, L. Kannan, T. S. Mor, Plant Mol. Biol., 2013, 81, 565-576.

[7] C. C. Akoh, G. C. Lee, Y. C. Liaw, T. H. Huang, J. F. Shaw, Prog. Lipid Res., 2004, 43, 534-552.

[8] D. J. Brick, M. J. Brumlik, J. T. Buckley, J. X. Cao, P. C. Davies, S. Misra, T. J. Tranbarger, C. Upton, FEBS Lett., 1995, 377, 475-480.

[9] J. Li, U. Derewenda, Z. Dauter, S. Smith, Z. S. Derewenda, Nat. Struct. Biol., 2000, 7, 555-559.

[10] A. Molgaard, S. Kauppinen, S. Larsen, Structure, 2000, 8, 373-383.

[11] Y. Y. Jiang, R. J. Chen, J. L. Dong, Z. J. Xu, X. L. Gao, Plant Omics, 2012, 5, 351-358.

[12] J. M. Ding, T. T. Yu, L. M. Liang, Z. R. Xie, Y. J. Yang, J. P. Zhou, B. Xu, J. J. Li, Z. X. Huang, J. Microbiol. Biotechnol, 2014, 24, 1551-1558.

[13] S. Abdelkafi, H. Ogata, N. Barouh, B. Fouquet, R. Lebrun, M. Pina, F. Scheirlinckx, P. Villeneuve, F. Carriere, Biochim. Biophys. Acta, 2009, 1791, 1048-1056.

[14] Z. X. Yang, Y. Zhang, R. Qiu, J. Huang, C. N. Ji, Acta Crystallogr. F, 2013, 69, 776-778.

[15] D. Deng, Y. Zhang, A. J. Sun, J. Y. Liang, Y. F. Hu, Appl. Biochem. Biotechnol., 2016, 179, 75-93.

[16] S. Y. Bae, B. H. Ryu, E. Jang, S. Kim, T. D. Kim, Appl. Microbiol. Biotechnol., 2013, 97, 1637-1647.

[17] X. P. Tian, S. K. Tang, J. D. Dong, Y. Q. Zhang, L. H. Xu, S. Zhang, W. J. Li, Int. J. Syst. Evol. Microbiol., 2009, 59, 948-952.

[18] C. S. Chen, Y. Fujimoto, G. Girdaukas, C. J. Sih, J. Am. Chem. Soc., 1982, 104, 7294-7299.

[19] M. Biasini, S. Bienert, A. Waterhouse, K. Arnold, G. Studer, T. Schmidt, F. Kiefer, T. G. Cassarino, M. Bertoni, L. Bordoli, T. Schwede, Nucleic Acids Res., 2014, 42, 252-258.

[20] Z. S. Derewenda, Y. Y. Wei, J. Am. Chem. Soc., 1995, 117, 2104-2105.

[21] C. X. Cui, R. Xie, Y. F. Tao, Q. Q. Zeng, B. Q. Chen, Biocatal. Biotransform., 2015, 33, 38-43.

[22] X. Li, S. S. Huang, L. Xu, Y. J. Yan, BMC Biotechnol, 2013, 13, 1-9.

[23] A. P. de los Rios, F. van Rantwijk, R. A. Sheldon, Green Chem., 2012, $14,1584-1588$.

[24] P. Xue, X. H. Yan, Z. Wang, Chin. Chem. Lett., 2007, 18, 929-932.

\section{Graphical Abstract}

Chin. J. Catal., 2016, 37: 1966-1974 doi: 10.1016/S1872-2067(16)62505-6

\section{Enantio-selective preparation of (S)-1-phenylethanol by a novel marine GDSL lipase MT6 with reverse stereo-selectivity}

Dun Deng, Yun Zhang, Aijun Sun, Yunfeng Hu *

South China Sea Institute of Oceanology, Chinese Academy of Sciences;

Institute of Animal Science, Guangdong Academy of Agricultural Science;

South China Sea Bio-Resource Exploitation and Utilization Collaborative Innovation Center

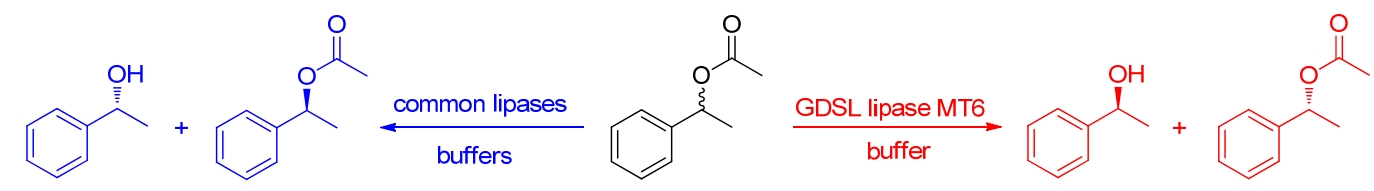

(R)-1-phenylethanol

(S)-1-phenylethanol

e.e. $>97 \%$

conversion $>28 \%$

A novel marine microbial GDSL lipase MT6 exhibits reverse stereo-selectivity than other general lipases in the preparation of $(S)$-1-Phenylethanol with high enantiomeric excess through direct hydrolytic reactions. 
[25] Y. Cao, Y. Zhuang, C. J. Yao, B. Wu, B. F. He, Biochem. Eng. J., 2012, 64, 55-60.

[26] M. Kawashima, T. Hasegawa, Biotechnol. Lett., 1993, 15, 465-468.

[27] F. Bellezza, A. Cipiciani, G. Cruciani, F. Fringuelli, J. Chem. Soc. Perkin Trans. 1, 2000, 4439-4444.
[28] X. L. Tang, J. Liu, B. Wang, H. W. Yu, World J. Microbiol. Biotechnol., 2011, 27, 129-136.

[29] J. Y. Liang, Y. Zhang, A. J. Sun, D. Deng, Y. F. Hu, Appl. Biochem. Biotechnol., 2016, 178, 558-575.

[30] A. Tahan, M. Monajjemi, Acta Biotheor., 2011, 59, 291-312.

\title{
一个具有相反光学选择性的新颖海洋 GDSL 脂肪酶MT6用于 (S)-1-苯基乙醇制备
}

\author{
邓盾 ${ }^{\mathrm{a}, \mathrm{b}, \mathrm{c}}$, 张 云 ${ }^{\mathrm{a}, \mathrm{b}}$, 孙爱君 ${ }^{\mathrm{a} . \mathrm{b}}$, 胡云峰 ${ }^{\mathrm{a}, \mathrm{b}, \mathrm{d}, *}$ \\ a 中国科学院南海海洋研究所, 中国科学院热带海洋生物资源与生态重点实验室, 广东广州 510301 \\ b中国科学院南海海洋研究所, 广东省海洋药物重点实验室, 广东广州 510301 \\ c广东省农业科学院动物科学研究所, 广东广州 510640 \\ d 南海生物资源开发和利用协同创新中心，广东广州 510275
}

\begin{abstract}
摘要: 1-苯乙醇是一种重要的手性药物中间体, 并且 $(S)$-1-苯乙醇和 $(R)$-1-苯乙醇均具有应用价值. 怎样获得光学醇的 1-苯 乙醇是药物合成中的重要问题. 传统的化学合成手段不仅反应过程复杂, 而且反应条件剧烈, 对环境污染严重, 因此生物 催化方法越来越受到重视. 脂肪酶和酯酶以其出色的立体选择性和温和的反应条件而被广泛用于手性药物的拆分制备. 但是之前的一些研究发现脂肪酶和酷酶大都对 $(R)$-1-苯乙醇及其衍生物有选择性, 而我们发现并鉴定的脂肪酶 MT6 的立 体选择性则与这些脂肪酶/酷酶完全相反, 具体体现在以下两个方面: (1) MT6 能够特异地催化 (S)-1-苯乙醇和乙酸异丙烯 酯的转酯反应, 生成 $(R)$-1-苯乙醇; (2) MT6 能够选择性地水解 (S)-乙酸苏合香酯, 生成 (S)-1-苯乙醇. 可见, 利用 MT6 催化 的转酯反应和水解反应可以巧妙地进行 (S)-1-苯乙醇和 $(R)$-1-苯乙醇的制备.

MT6 来源于深海放线菌 Marinactinospora thermotolerans SCSIO 00652, 属于 GDSL 家族脂肪酶第 II 类群, 这一类群的 脂肪酶绝大多数来自微生物. 有关 GDSL 家族脂肪酶在手性拆分中的应用研究非常少. 我们之前报道了 MT6 的克隆、表 达、纯化及转酯拆分反应, 本文重点考察了 MT6 通过水解反应制备 (S)-1-苯乙醇的条件, 优化了酶促水解拆分反应温度、 有机共溶剂、 $\mathrm{pH}$ 、离子强度、酶用量、底物浓度、反应时间以及底物侧链长度等参数. 研究发现, 在反应体系中加入一定 量的有机共溶剂能够大大提高产物 (S)-1-苯乙醇的光学纯度, 其中添加二氯甲烷获得的结果最为理想, 可以将产物光学纯 度从 $43 \%$ 提高到 $89 \%, E$ 值从 2.84 提高至 22.82. 经过优化, 最佳反应温度为 $40^{\circ} \mathrm{C}$, 共溶剂二氯甲烷浓度为 $5 \%$ (体积分 数), 反应缓冲液为 $0.1 \mathrm{~mol} / \mathrm{L}$ Tris- $\mathrm{HCl}(\mathrm{pH}=7.0)$, 酶用量为 $150 \mathrm{mg} / \mathrm{mL}$, 底物为 $15 \mathrm{mmol} / \mathrm{L}$ 乙酸苏合香酯, 反应时间控制在 12 h. 在此条件下, 制备的 (S)-1-苯乙醇的光学纯度可达 $97 \%$, 转化率可达 $28.5 \%, E$ 值为 95.9 . 此外, 还比较了侧链长度不 同的 1-苯基乙醇酯对水解反应的影响, 结果表明 1-苯基乙醇酯的侧链长度可极大影响光学选择性和产率. 在反应条件相 同时, MT6 催化侧链长度为 4 个碳的丁酸-1-苯乙酯水解, 生成 (S)-1-苯乙醇的光学纯度仅为 $50 \%$. 利用 AutoDock 软件进 行分子对接, 结果显示长侧链的 1-苯基乙醇酯离活性中心 His230 的咪唑基较远, 可能是导致酶立体选择性低的重要原因.

值得注意的是, 海洋微生物来源的 GDSL 脂肪酶 MT6 在水解反应和转酯反应中均表现出与一些已知脂肪酶/醌酶相反 的立体选择性, 因而具备进一步开发和应用价值. 所制备的 (S)-1-苯乙醇的光学纯度为 $97 \%$, 可以通过和转酯反应相结合 的方式进一步提高产物的光学纯度和转化率.
\end{abstract}

关键词: GDSL 脂肪酶; 生物催化; 动力学拆分; 直接水解; (S)-1-苯基乙醇; 相反的光学选择性

收稿日期: 2016-05-31. 接受日期: 2016-07-13. 出版日期: 2016-11-05.

*通讯联系人. 电话: (020)89024092; 传真: (020)84451672; 电子信箱: yunfeng.hu@scsio.ac.cn

基金来源：中国科学院战略性先导科技专项 (XDA11030404); 国家自然科学基金 (21302199); 广州市科技计划 (201510010012);

中国科学院重点项目 (KGZD-EW-606).

本文的英文电子版由Elsevier出版社在ScienceDirect上出版(http://www.sciencedirect.com/science/journal/18722067). 